\title{
Questão Social \& Qualidade de Vida: estudo de caso dos imigrantes haitianos em Manaus
}

\section{Social Issues \& Quality of Life: a case study of Haitian immigrants in Manaus}

\author{
Maria Do Perpétuo Socorro Rodrigues Chaves* \\ Richemond Dacilien ${ }^{\star *}$ \\ Letícia Carla Letícia Carvalho**
}

\begin{abstract}
Resumo: Este artigo aborda as condições de vida de imigrantes haitianos na cidade de Manaus, no ano de 2019, no estudo da dissertação "Condições de Vida dos Imigrantes Haitianos no Centro de Acolhimento da Pastoral de Migrante, Manaus/Am", e no projeto Análisis Multidimensional de las Interacciones Universidad-Sociedad en el Estado del Amazonas, do Grupo Interação, da Red Multiben, do Programa Iberoamericano de Ciência e Tecnologia para o Desenvolvimento - CYTED. Os procedimentos metodológicos foram pautados na Metodologia Interação, uma abordagem crítico dialética, abrangendo pesquisa bibliográfica, documental e de campo com técnicas e instrumentos de caráter participativo. Os resultados sintetizam os debates teórico práticos sobre como a questão social em suas expressões econômicas (empobrecimento, desemprego), políticas (limites à participação), sociais (exclusão social, relações de subalternidade), ambientais (riscos e vulnerabilidade aos desastres naturais) e culturais (desvalorização de seus saberes e práticas) afetam a qualidade de vida dos imigrantes haitianos.
\end{abstract}

Palavras-chave: Cidadania. Qualidade de Vida. Questão Social.

\begin{abstract}
This article discusses the living conditions of Haitian immigrants in the city of Manaus, in 2019, based on the studies carried out in the dissertation "Living Conditions of Haitian Immigrants in the Reception Center for Pastoral Care of Migrants, Manaus / Am" and in the project Análisis Multidimensional de las Interacciones Universidad-Sociedad en el Estado del Amazonas, by researchers from Grupo Interação, from Red Multiben, from the
\end{abstract}

\footnotetext{
*Doutora em Política Científica e Tecnológica, Professora Titular da Universidade Federal do Amazonas do Departamento de Serviço Social. Coordenadora do Grupo Interdisciplinar de Estudos Socio-ambientais e de Desenvolvimento de Tecnologias Apropriadas na Amazônia (Grupo Inter-Ação) Bolsista Produtividade CNPq. E-mail: socorro.chaves@outlook.pt.

** Doutorando em Política Social /UFES, Mestre em Serviço Social e Sustentabilidade na Amazônia- PPGSS/UFAM. Pesquisador do Grupo Interdisciplinar de Estudos Socioambientais e de Desenvolvimento de Tecnologias Apropriadas na Amazônia (Grupo Inter-Ação), E-mail: dacilienr@gmail.com.

*** Graduanda em Serviço Social na UFAM. Pesquisadora de Iniciação Cientifica do Grupo Interdisciplinar de Estudos Socioambientais e de Desenvolvimento de Tecnologias Apropriadas na Amazônia. E-mail carlaleticiaseso@gmail.com.
} 
Iberoamerican Science and Technology for Development Program - CYTED. The methodological procedures, in a critical dialectical approach based on the Interaction Methodology, covered bibliographic, documentary and field research with techniques and instruments of a participatory character. The results summarize the theoretical and practical debates on how the social issue in its economic expressions (impoverishment, unemployment), political (limits to participation), social (social exclusion, subordinate relationships), environmental (risks and vulnerability to natural disasters) and cultural (devaluation of their knowledge and practices) affect the quality of life of Haitian immigrants.

Keywords: Citizenship. Quality of Life. Social Issues.

Recebido em: 20/03/2020. Aceito em: 22/07/2021

\section{Introdução}

Este artigo aborda as condições de vida dos imigrantes haitianos na cidade de Manaus, a partir do debate que articula dois trabalhos de pesquisa: a dissertação intitulada "Condições de Vida dos Imigrantes Haitianos no Centro de Acolhimento da Pastoral de Migrante, Manaus/ Am" (Parecer de aprovação do Comitê de Ética em Pesquisa/UFAM, no. 3.460.098), com bolsa de pesquisa CNPq, e no projeto Análisis Multidimensional de las Interacciones Universidad-Sociedad en el Estado del Amazonas, ambos vinculados ao Grupo Interdisciplinar de Estudos Socioambiental e Desenvolvimento de Tecnologias Sociais na Amazônia - Grupo Interação, da Red Multiben, apoiado com recursos do Programa Iberoamericano de Ciencia y Tecnología para el Desarrollo - CYTED, órgão dos governos dos países Ibero-americanos para cooperação em Ciência, Tecnologia e Inovação para o desenvolvimento dos países Ibero-Americanos. A Red Multiben envolve 14 grupos de pesquisas do Brasil,da Argentina, do Uruguai, da Espanha, da Costa Rica, de Portugal e da Colômbia.

Os estudos foram realizados, no ano de 2019, com imigrantes haitianos na cidade de Manaus, a partir de abordagem baseada na perspectiva crítico dialética. A natureza dos dados coletados é qualiquantitativa, com prioridade para a análise qualitativa, utilizando as informações quantitativas como subsidiárias. Os procedimentos metodológicos foram ordenados pela Metodologia Interação, abrangendo: pesquisa bibliográfica, documental e de campo com observação direta e participativa aplicadas no decorrer de diversos eventos organizados com os imigrantes haitianos; a realização de entrevistas semiestruturadas com 10 indivíduos. A abordagem analítica para interpretação dos relatos foi pautada pela técnica de análise do conteúdo.

No escopo deste artigo foram abordadas as condições que incidem sobre a qualidade de vida dos imigrantes na cidade de Manaus, no Estado do Amazonas. As bases conceituais da matriz de abordagem analítica explicativa da teoria crítica marxista foram utilizadas para tratar sobre a questão social e, mais especificamente, para discutir as distintas manifestações que decorrem de sua emergência sócio-histórica, pelo reconhecimento de que "o marxismo é a filosofia insuperável de nosso tempo. Ele é insuperável porque as circunstâncias que a engendram não foram superadas." (SARTRE, 1972, p. 25). Outrossim, a partir de estudos de diversos autores aborda-se o 
conceito de cidadania, cuja seleção foi efetuada em função do reconhecimento de que fornecem elementos para um efetivo diálogo crítico no campo das Ciências Sociais.

\section{Questão Social \& Cidadania, bases sócio-históricas}

A questão social teve sua gênese na Europa, no século XIX, à medida que a acumulação de riqueza expandia-se exponencialmente, e a pobreza crescia na mesma proporção, em função da riqueza socialmente produzida seguir sendo expropriada e concentrada sob a propriedade da classe burguesa dominante. Nos anos de 1830, pela primeira vez, o termo questão social foi cunhado, um século antes de ser reconhecido no Brasil.

Entende-se que a questão social é resultado do processo que abrange dois fenômenos associados entre si: a usurpação/expropriação dos segmentos sociais no campo e as condições precárias de existência vivenciada por extensa parcela dos moradores da cidade como trabalhadores no âmbito da sociedade urbana-industrial. Para Netto (2012, p. 92-93).

As sociedades pré-capitalistas, as mais remotas e as mais próximas de nós, conheceram e conhecem fenômenos de polarização, pobreza e abundância e fenômenos de desigualdade. O que é novo na sociedade capitalista - o que é radicalmente novo na sociedade capitalista - é o fato de que nela estão dadas as condições e as possibilidades de suprimir as carências materiais da massa da população.

Os avanços históricos ocorridos nos moldes da exploração na sociedade mudaram radicalmente com o advento do capitalismo, Em Que o plebeu passou para a condição de trabalhador livre, que ao ter suas terras expropriadas e inserido em um modo de produção que o explorou de maneira desumana e exacerbada, passou a depender da venda da sua força de trabalho para a sua sobrevivência. Contraditoriamente, as configurações e a dinâmica do modo de produção instaurado permitem condições para alcançar a produção necessária para a satisfação das necessidades humanas em escala mundial, todavia, em função do caráter exploratório dos trabalhadores na sociedade de classes, o que se expressa é o acelerado crescimento do pauperismo e das desigualdades sociais.

De acordo com a definição feita por Iamamoto (1999), a questão social compreende o conjunto das expressões das desigualdades sociais da sociedade capitalista, cuja matriz comum é a produção social coletiva, o trabalho social e a apropriação privada dos seus resultados, sob o monopólio de uma fração muito pequena da sociedade. Para esta autora, um dos imperativos da atualidade é a necessidade de repensar a questão social, tendo em vista que suas bases de produção passaram por transformações em razão das mudanças no padrão de acumulação. Iamamoto (1999, p. 29) afirma que:

Os '30 anos gloriosos' - do pós-guerra até meados dos anos 1970 - marcaram uma ampla expansão da economia capitalista, sob a liderança do capital industrial, apoiada em uma organização da produção de bases tayloristas e fordistas, como estratégias de organização e gestão do processo de trabalho.

Para a autora supracitada, a constituição histórica da questão social, em sua gênese, resulta da contradição básica da sociedade: a produção social com a apropriação privada do trabalho, suas condições e seus resultados. Essa forma de apropriação determina as condições de desigualdade socioeconômica e política no interior da sociedade. Na visão de Iamamoto (2012), a questão social 
está relacionada à "emergência do trabalhador livre", desprovido de propriedade, cuja "liberdade" implica na possibilidade de vender sua força de trabalho para a realização do processo produtivo que redunda na produção do capital, que sob a égide da exploração sustenta a reprodução da vida social. Portanto, a questão social abrange as desigualdades sociais entre as classes sociais em suas manifestações de gênero, raça, etnia, religião, nacionalidade, meio ambiente, entre outras. Todavia, faz-se necessário considerar que na dinâmica da sociedade, também ocorrem a manifestação de variadas formas de resistência e lutas sociais.

Outro autor importante neste debate é Cerqueira Filho (1982), que entende a questão social como sendo um intricado arranjo de problemas econômicos, políticos e sociais que emergiram com a constituição da classe operária na sociedade capitalista. Assim, de acordo com a indicação do autor, pode-se afirmar que a gênese da questão social se manifesta no cerne do conflito entre trabalho e capital.

O referido autor indica que a emergência da questão social aparece como problema no final do século XIX. Segundo Cerqueira Filho (1982), na conjuntura econômica e social de consolidação do capitalismo no Brasil, marcada pela transição do escravismo (mão de obra escrava) para o sistema capitalista (mão de obra assalariada), que ocorreu nos primórdios da industrialização no eixo RioSão Paulo, emergiu uma incipiente classe operária, dando feição ao embrião da questão social.

No Brasil e no mundo, o meio urbano coadunou o processo de industrialização, que foi pautado pela expansão do modo capitalista de produção e conduzido pela emergência do setor industrial sob a condução da burguesia de um lado e de outro pela constituição do operariado, que expôs à luz a questão social, tornando-a reconhecida como um "problema real".

No Brasil, o referido processo, embora tenha gerado transformações econômicas, sociais, políticas e culturais, somente adquiriu caráter extensivo a partir da década de 1930. No decorrer da Primeira República, dominada pelas oligarquias agrárias, os problemas que constituíam a questão social eram tratados como "caso de polícia”. Até a década de 1930, a questão social era escamoteada pelos discursos oficiais para se evitar a visibilidade. Os problemas sociais eram identificados como eventuais, embora já fossem um fenômeno real. Ao final da referida década, o Governo, por meio do Ministério do Trabalho, desenvolveu alternativas trabalhistas para solucionar a questão social, todavia, atuou, também, de modo repressivo junto aos setores empobrecidos que reivindicavam direitos.

Cerqueira Filho (1982) declara que ocorreu uma distinção substancial em relação ao momento histórico anterior: se antes de 1930, a questão social foi tratada como ilegal, "caso de polícia", não reconhecida pelo Estado e pela fração de classe que estava no poder, a situação passou por uma mudança sutil, isso porque, apesar da repressão e do paternalismo característico do momento, a questão social deixou de ser considerada uma questão ilegal. Rico (1998) destaca que, a partir da década de 1970, verifica-se a expansão das atividades associativas civis e o aumento dos investimentos privados na questão social, o que caracterizou um modo político e econômico de organização das forças produtivas mais do que a mera expressão da solidariedade e do associativismo.

Neste debate, novos elementos para o estudo da questão social foram apresentados por Castel (1998; p.21) que os definiu como as "metamorfoses da questão social", afirmando que:

A situação atual é marcada por uma comoção que, recentemente, afetou a condição salarial: o desemprego em massa e a instabilidade das situações de trabalho, a inadequação dos sistemas clássicos de proteção para dar cobertura a 
essas condições, a multiplicação de indivíduos que ocupam na sociedade uma posição de (...) empregados de um modo precário, intermitente.

Na contemporaneidade é possível reconhecer que a questão social opera como reptos e dilemas que consomem e minam as condições emancipatórias dos sujeitos em sociedade. Sob égide destrutiva e avassaladora que forja a questão social, imposta pela ordem econômica, no plano da sociedade são produzidos imensos abalos na tomada de consciência dos cidadãos, em um processo contínuo que acentua o grau de empobrecimento, que nega a dignidade e desmoraliza parcela expressiva de segmentos sociais visando a limitar suas capacidades de fazer valer seus direitos de cidadania.

O debate apresentado permite perceber que a questão social é fruto das relações contraditórias que vigoram no cerne da sociedade capitalista. À luz da teoria crítica (lê-se marxista), toma-se como pressuposto que as relações sociais são norteadas/determinadas pela prática social fundada no modelo das relações de produção na sociedade de classes. Posto que o modo de produção capitalista, em sua dinâmica, resulta no processo de acumulação privada de riquezas, na propriedade privada dos meios de produção e na afirmação da exploração via compra da força de trabalho. Esse processo é regido pelo enfrentamento, velado e/ou explícito, entres classes sociais com interesses antagônicos, ou seja, entre trabalhadores e aqueles que compõe a classe dominante, proprietários dos meios de produção, tendo em vista a relação exploratória e desigual entre o capital e trabalho, que produz contradições no seio da produção e reprodução da vida social.

Segundo Iamamoto (2012, p. 156), a questão social “(...) condensa o conjunto das desigualdades e lutas sociais, produzidas e reproduzidas no movimento contraditório das relações sociais, alcançando plenitude de suas expressões e matizes em tempo de capital fetiche."

Um estudo de 2015, publicizado pela organização não-governamental britânica Oxfam, que com dados do banco Credit Suisse, apresenta um exemplo que evidencia a concentração e a acumulação do capital, ao expor em suas conclusões que $95 \%$ da riqueza socialmente produzida está concentrada nas mãos de apenas 5\% população mais abastada do mundo. Outro exemplo, divulgado, em 2016, pela Organização das Nações Unidas para Agricultura e Alimentação (FAO), indica que a produção de alimentos mundial pode atender a demanda da população da terra.

Nesta direção, Ianni (1994, p. 4) alega que a complexidade da questão social, no que concerne às circunstâncias que norteiam a realidade concreta, compreende a síntese de múltiplas determinações:

A questão social apresenta diferentes aspectos econômicos, políticos e culturais. Algumas vezes envolve, principalmente, operários, outras camponeses. Aqui, podem estar os negros, lá os índios. Sem esquecer que em muitas vezes é o outro. As reivindicações, os protestos e as revoltas não se esgotam no âmbito da economia e da política, podendo implicar em aspectos culturais.

Conforme explicita o autor supracitado, as múltiplas refrações da questão social reluzem seus matizes em profusas dimensões da produção e da reprodução da vida social, abrangendo de maneira complexa as dimensões política, econômica, social e cultural. Vale enfatizar ainda o reconhecimento da existência de um outro fator importante nesta equação, a dimensão ecológica que é integrada pelos recursos naturais. Embora os recursos naturais que compõem o meio ambiente sejam elementos essenciais à vida em todas as suas formas, também são imprescindíveis à produção material que, na saga pelo incremento da produção para atender o consumo 
desenfreado, sofrem agravos profundos. Esse conjunto conexo e interdependentes de contradições ao acesso à cidadania interfere na qualidade de vida dos agentes e dos atores que estão no seio das engrenagens da sociedade capitalista, ou melhor dizendo, atinge inexoravelmente àqueles que atuam na geração do movimento das engrenagens do sistema.

O conceito de cidadania, por sua vez, alcançou relevância central nos fóruns de debates acadêmicos e políticos, sempre assinalado por controvérsias em meio a interesses contrapostos dos grupos e setores sociais. A cidadania, na qualidade de fenômeno social, que se concretiza e é compartilhada no cotidiano da vida política, somente pode ser entendida na dinâmica da interface indivíduo-sociedade e na interconexão entre indivíduos em um meio social.

Assim sendo, a cidadania caracteriza um fenômeno com múltiplas interfaces e composta por diversas dimensões (política, econômica, social, ambiental e cultural), abrangendo amplitude com demarcações flexíveis e, por conseguinte, ganhando campo de múltiplas disciplinas. (SPINK, 1994, p. 09). Portanto, a cidadania transcende os domínios das disciplinas específicas abrindo espaço para participação de autores de filiações disciplinares diversas. Assim sendo, esse conceito é requisitado a percorrer variados temas nos campos da Ciência Política, Psicologia Social, Sociologia, Antropologia, Psicanálise. (SPINK, 1994, p. 10).

Conforme afirma Spink (1994,p. 10), a cidadania em sua multiplicidade abrange um conjunto de:

(...) elementos históricos, determinações estruturais, subjetividade e até mesmo o prenúncio de uma ruptura iminente de epistéme que leva a ampliar o conceito para incluir aí não mais apenas os direitos construídos à luz das teorias da igualdade, como também a integração criativa da diferença, da ética e até mesmo, ou sobretudo, da felicidade.

Diferentes debates e estudos reiteram que no Brasil não ocorreu a universalidade das leis, o que implica o reconhecimento de que a cidadania não é uma condição acessível ao conjunto da sociedade brasileira: enfim, as premissas garantidas pela cidadania não são universalizadas no país. Para Pinheiro (1992 apud SPINK, 1994), por não existirem “controles democráticos" em relação aos governos, tal situação, em conjunto com os limites de acesso aos direitos humanos impostos para as populações pauperizadas, conserva no País uma acentuada hierarquização social. A hierarquização vigente é sustentada pelas raízes do paternalismo, pelas garras da precariedade, das estratégias de sobrevivência, fomentada e nutrida pela economia de subsistência mantida sob condição de exclusão social.

Bendix (1966 apud SPINK, 1994, p. 17) assevera que, no Brasil, a cidadania teve seu desenvolvimento limitado e que, portanto, não procede do entendimento que preconiza: “(...) aqueles que contribuem para a riqueza e o bem-estar do seu país têm o direito de serem ouvidos, merecem um status de respeito". Em concordância com a premissa apresentada, entende-se que nas políticas públicas efetivadas no Brasil não fica explícito e nem encontra abrigo o entendimento ou o reconhecimento de que os direitos sociais procedem da efetiva geração de bens e serviços que cada cidadão produz como atributo da cidadania e que constitui a real riqueza da nação.

Ao considerar que a cidadania implica no acesso aos direitos sociais, sua construção vincula-se à difusão de uma cultura democrática. Spink (1994) defende que a construção da cidadania democrática requer formas de proteção em relação ao poder arbitrário, tornando imperioso que os cidadãos disponham de mecanismos de controle sobre os governantes. Outrossim, a autora entende que se faz necessário que os cidadãos internalizem seus direitos sociais, e, para tal, é 
mister ter oportunidade de atuar e sentir-se partícipes ativo na formulação das políticas públicas, e, desse modo considerá-las como fruto de um pacto social mantido entre pares, superando o alijamento que vigora.

Os movimentos sociais, historicamente constituídos no Brasil como artefato de luta de classes, representam as vozes dos demandantes por bens e serviços sociais que abrangem diversas esferas da vida, tais como saúde, habitação, saneamento, educação, meios de transportes entre outros. Na legitimidade da luta e para além das demandas materiais, as reivindicações representam a luta pela superação da subalternidade com a construção do protagonismo social, da afirmação de identidades culturais, da defesa de direitos em uma crítica frontal às formas de negação e subordinação a que são expostos ao longo da formação social do país. (SPINK, 1994).

O pressuposto apresentado pela autora é de que mesmo que o conceito de cidadania seja polissêmico, guardando conteúdos diversos, a centralidade de sua contribuição baseia-se na afirmação de que o que confere a condição de cidadão é a garantia da participação social consciente e o acesso às políticas públicas (serviços e bens sociais) dispostos da sociedade.

A cidadania efetiva-se de forma regulada pelo Estado, incidindo na esfera da produção e, posteriormente, na viabilização de políticas públicas de corte social (stricto sensu). Logo, acepção do termo, explicita seu papel de nortear as relações e as práticas políticas no âmbito da sociedade.

No contexto de formação sociopolítica do Brasil, a Carta Magna Brasileira de 1988 assegura, em seu artigo 1ํㅜ a cidadania como fundamento do Estado Democrático de Direito. Mas afinal, o que é cidadania? Marx no ensaio intitulado "Sobre a Questão Judaica”, de 1843, apresenta uma crítica à concepção de direitos humanos sob moldes da sociedade burguesa, que mantém as condições de exploração ao passo que oferta aos despossuídos uma restrita condição de cidadão. Nesta obra, Marx (2010; p. 52) contrapõe-se às concepções idealistas inspirados em Hegel de Bruno Bauer, inclusive delineando neste trabalho as bases do materialismo histórico e dialético, em que para ele:

[...] a realização plena do idealismo do Estado representou concomitantemente a realização do materialismo da sociedade burguesa. $O$ ato de sacudir a si o jugo político representou concomitantemente sacudir de si as amarras que prendiam o espírito egoísta do capitalismo [...].

Em 1950, Thomas Marshall, em seu livro "Cidadania, Classes Sociais e Status”, formulou um conceito liberal-democrata, que reconhece a extensão do status de cidadão aos novos atores e agentes da sociedade. Marshall (1967) propõe a categorização do conceito de cidadania em um tripé: 1) direitos civis, que correspondem à liberdade individual, de ir e vir, de pensamento, credo, dentre outros exemplos; 2) direitos políticos, que fazem referência à liberdade política, partidária, de votar e ser votado, participar de movimentos sociais, entre outras formas de atuação política; 3) direitos sociais, que dizem respeito ao acesso e usufruto aos bens e serviços sociais em atendimento às necessidades básicas de reprodução social e do bem-estar físico dos grupos sociais.

Esta concepção fundamentada em Marshall não denuncia as contradições produzidas pela dicotomia capital/trabalho, pois defende que a "a igualdade não se refere tanto a classes", aposto que parte do entendimento de que "a igualdade de status é mais importante do que a igualdade de renda”. Portanto, vê-se uma concepção que eleva o aparato jurídico-político legal, em função das contradições do modo de produção capitalista, sem, contudo, reconhecer e evidenciar à questão da divisão entre as classes sociais, que seja a desigualdade que resulta das contradições inerentes ao modo de produção do capital. 
Numa notória contraposição à Marshall, Coelho (1990, p. 24) indica que “(...) alcançar, pois, a cidadania, não é possuir um status como diz Marshall: é avançar no estado de consciência social que é o cerne do coletivo."

Sobre a categoria qualidade de vida, ressalta-se que ao considerá-la sob o foco do conceito de cidadania em seu tripé (direitos civis, direitos sociais, direitos políticos), embora seja uma categoria determinante para a consolidação de uma vida satisfatória, percebe-se que a mesma está circunscrita a enunciados sem propor efetivamente o rompimento da estrutura que mantém as desigualdades sociais.

De uma maneira geral, a cidadania sofre sérias distorções, seja conceitual, seja na sua concretização, pois se a universalização do acesso qualificado ao acesso aos bens e serviços sociais não está efetivamente garantido, registra-se a negação da condição de cidadania. De acordo com o exposto entende-se que os direitos sociais que derivam da cidadania em si são determinados pela universalização do acesso aos bens e serviços sociais. Em síntese, o debate sobre a cidadania basicamente implica em reconhecer um conjunto de premissas apresentadas por Spink (1994), que assevera que o termo cidadania em seu arcabouço abrangente indica:

a) um fenômeno social polissêmico instituído na relação indivíduo-sociedade;

b) uma condição constituída por expressões multiformes;

c) a abrangência de variados campos científicos, avançando nos contornos e limites disciplinares;

d) a existência da adoção e (re)combinação de diversos enfoques e temáticas variadas;

e) a associação entre elementos de base conjuntural, histórica, estrutural, subjetivos e materiais, técnico-científico.

Para Faleiros (1989), o debate sobre cidadania desvenda que a construção da cidadania abrange: um processo ideológico de formação da consciência pessoal e social de direito e deveres; e, também, o reconhecimento formal dos mesmos num Estado de Direito. Ambos se concretizam na luta contra as discriminações, na superação de barreiras de segregação entre indivíduos, no combate às diversas formas de opressão, no acesso às políticas públicas e na participação nas decisões que envolvem os interesses da nação.

Assim, será fundamental debater os liames conceituais e sócio-históricos do termo qualidade de vida para entender de que forma a mesma se concretiza na realidade de uma população, mais especificamente para tratar do estudo de caso dos migrantes haitianos na cidade de Manaus, sob a força dos limites da cidadania, que se expressa em relação ao acesso a bens e serviços sociais na sociedade contemporânea.

\section{Qualidade de Vida na Dinâmica da Sociedade Contemporânea}

O conceito de qualidade de vida ainda guarda muita inconsistência e imprecisão teórica, apresentando-se de forma diversificada, e até mesmo divergente, assumindo caráter complexo. Mediante este cenário, faz-se imperativo assumir o desafio de contribuir com os esforços de diversos estudiosos de debater e buscar construir sendas para desvendar seus entornos, contornos, limites, possibilidades. Vale ressaltar que a maneira como são abordadas nos estudos as questões concernentes à qualidade de vida, bem como as referências aceitas possuem vínculos intrinsecamente relacionados aos parâmetros de caráter técnico, mas também políticos, no campo investigativo. 
Os pesquisadores da temática qualidade de vida caminham fortemente para o desenvolvimento de metodologias e técnicas de abordagem que fomentem a elaboração de ferramentas teóricas e práticas para proceder ao tratamento técnico-científico dos temas que se entrelaçam de modo tão complexo, que abrangem categorias, tanto abstratas quanto operacionais, e envolvem fatores objetivos, materiais e subjetivos.

No início da década de 1990, com a finalidade de contribuir para avançar na busca da produção de maior precisão teórica para a categoria, a Organização Mundial de Saúde reuniu especialistas de variadas áreas para o espraiamento acerca do tema nomeado de Group Word Heath Organization Quality of Life (Grupo WHOQOL). Para o Grupo WHOQOL (1993), a terminologia qualidade de vida refere-se à percepção do sujeito, sendo alicerçada na posição que o mesmo ocupa na dinâmica da vida em sociedade e no domínio dos valores inerentes à sua base cultural, a que orienta seu modo de vida e nas relações que estabelece na cena societal, assim como dos objetivos, das expectativas, dos padrões e das preocupações que possui mediante a existência. esta concepção reflete a natureza subjetiva do conceito de qualidade, bem como denota a configuração do conceito em sua imersão junto às múltiplas dimensões da vida (social, cultural, política, ambiental).

Ao tratar sobre qualidade de vida é importante percebê-la a partir de uma visão integrada, em que os aspectos subjetivos e objetivos associam-se. para Barbosa (1998; p. 206-207):

(...) o conceito de qualidade de vida, ou da forma como é encarada, deverá constituir-se da visão que o sujeito, enquanto participante de uma sociedade urbana-industrial, tem da sua própria vida, de seu ambiente social e do grupo ao qual pertence.

Tendo em vista a complexidade do tema, Pereira, Teixeira e Santos (2012) indicam que há variadas abordagens ${ }^{1}$ e áreas de interesse que se instituem na constituição dos enfoques adotados. Os estudos sobre qualidade de vida são categorizados por Day e Jankey (1996) em quatro abordagens gerais, sendo elas: holística, socioeconômica, psicológica, biomédica e geral. A qualidade de vida, sob o prisma da abordagem holística, desborda múltiplas dimensões, expressando um ordenamento complexo e dinâmico de seus elementos e características, em que valores e interesses são de relevância para essa abordagem. No caso da abordagem socioeconômica, supõe-se considerar os indicadores sociais e o acesso a bens e serviços sociais. a abordagem psicológica leva em consideração as reações subjetivas dos indivíduos acerca de suas vivências e relações sociais. A biomédica remete às condições de saúde, à capacidade de viver plenamente em concomitância com o bem-estar usufruído na vida. Ao contemplar esse conjunto de abordagens, torna-se perceptível que todas as abordagens possuem limites e potencialidades.

Posto isto, neste ensaio sob égide do materialismo-histórico-dialético, busca-se analisar a sociedade a partir da base material de produção e do modo de consumo, visualizando os processos históricos engendrados a partir das contradições vigentes nas relações sociais determinadas pela dinâmica da sociedade capitalista e pelo desvendamento das expressões da questão social e de cidadania. Sob tal perspectiva, para proceder a um approach analítico crítico da qualidade de vida, em seus elementos concretos, sem, contudo, obliterar os elementos subjetivos/ideais, neste trabalho, todavia, estes elementos serão tratados de maneira tangencial, sem aprofundar seu papel na equação da dinâmica da vida dos sujeitos.

\footnotetext{
${ }^{1}$ Saúde (MICHALOS, ZUMBO \& HUBLEY, 2000; SCHMIDT, POWER, BULLINGER \& NOSIKOV, 2005); Felicidade e Satisfação Pessoal (RENWICK \& BROWN, 1996); Condições de Vida (BUSS, 2000); Estilo de Vida (NAHAS, 2003).
} 
Assim, a busca central apresentada neste artigo pautar-se-á pela construção de bases analíticas para o desvendamento das expressões da questão social e da cidadania na sociedade burguesa, de maneira mais específica no estudo da vida dos migrantes haitianos na cidade de Manaus. Considerando que ao tratar sobre a qualidade de vida, as contradições engendradas no cerne das relações sociais são fatores determinantes. Para tal, faz-se necessário fugir aos esquemas que, conforme ressalta Santin (2002), ao se referirem à qualidade de vida, geralmente, partem do entendimento de que se trata de algo bom, íntegro e positivo, sendo uma referência de existência de boa e digna.

Portanto, às vistas do que foi exposto e inscrita em uma realidade permeada de contradições, em uma sociedade marcada por relações desiguais e sob jugo de interesses antagônicos, emerge a questão para reflexão: será que é possível delimitar esse conceito de qualidade de vida como deleite e usufruto de bem-estar?

Apesar do aparato jurídico-político legal assegurando a garantia do tripé de direitos (civis, sociais e políticos), que alicerça o conceito de cidadania, não é possível defender que as condições materiais concretas e subjetivas estão disponíveis para usufruto, tendo em vista as contradições de classe inerentes ao modo de produção da sociedade. Isto gera um rebatimento que atinge por diversos ângulos a qualidade de vida em sociedade, em suas diversas abordagens, sejam elas socioeconômicas, psicológicas, biomédicas e holísticas.

$\mathrm{Na}$ abordagem socioeconômica, o desemprego estrutural vigente no sistema capitalista, a flexibilização e precarização das relações de trabalho, a desigualdade inerente ao modo de produção, a mercantilização de necessidades humanas como as condições de educação, moradia, alimentação e saúde, o individualismo presente nas relações e, por fim, todo o acúmulo e o entrelaçamento de problemáticas que emergem sob a égide do modo de produção e consumo de bens e serviços expressam e conotam as (sobre)determinações que atuam na qualidade de vida dos agentes sociais.

Portanto, os limites de acesso à bens e serviços sociais inerentes à condição de cidadania compromete de maneira intensa a condição dos trabalhadores. Tendo em vista que enfrentam condições adversas, que estão alicerçadas na negação do reconhecimento da classe trabalhadora como geradora de riqueza, que representa uma forma simbólica de usurpação de seu essencial papel no processo de produção. Por outro lado, verifica-se que os trabalhadores sofrem uma outra forma de usurpação, esta de cunho real, em função da apropriação da mais-valia relativa e absoluta que ocorre no processo de acumulação do capital. Assim concretiza-se uma dupla usurpação que redunda em interesses antagônicos entre as classes sociais

$\mathrm{Na}$ abordagem psicológica, que guarda uma conotação mais subjetiva, as expressões da questão social afetam drasticamente como os indivíduos percebem o mundo, sob a ótica sociocultural. Todavia, a qualidade de vida incorpora elementos subjetivos, simbólicos e psicossociais, mas também aqueles que envolvem condições materiais, que em conjunto abrangem valores, normas e regras sociais que regem a sociedade/grupo social nos quais os indivíduos formam sua identidade sociopolítica e cultural e implicam numa efetiva síntese das múltiplas determinações.

Na abordagem biomédica, a negação de uma saúde de caráter público, universal e de qualidade, a desumanização do atendimento e a mercantilização de necessidades humanas, entre outros limites, são fatores determinantes para limitar a qualidade de vida. Assim, esta abordagem reporta-se às privações e as negações de elementos essenciais à vida de qualidade em concomitância com a saúde plena. Enquanto na abordagem geral, o enfoque fenomenológico centra-se na intencionalidade do sujeito como elemento principal e determinante, por configurar o conceito 
de qualidade de vida sob a dependência da intencionalidade do sujeito, como categoria fundante da deterioração da qualidade de vida. No estudo em pauta, por considerar o materialismo-histórico-dialética na abordagem e no manuseio da categoria qualidade de vida, entende-se que a abordagem geral apresenta uma configuração com extrema limitação sobre as manifestações da questão social, em suas variadas dimensões da produção e reprodução da vida social.

Compreende-se, portanto, que a qualidade de vida deve ser abordada a partir de uma perspectiva crítica, que vislumbra a totalidade da realidade, no caso, considerando as múltiplas categorias. Nesta direção, entende-se que os principais fatores que incidem sobre a qualidade de vida dos indivíduos de uma sociedade são as condições do ambiente de atendimento das carências do ser humano (aspectos subjetivos) e da satisfação das necessidades materiais para reprodução social e física.

Enfim, é importante considerar não apenas os fatores que concorrem para satisfação das necessidades essenciais dos homens/mulheres, como alimentação, educação, saúde, lazer, trabalho), mas, também, é fundamental considerar como essas demandas estão sendo atendidas. A qualidade de vida, pelo prisma da cidadania, depende das condições de participação dos indivíduos na vida social, do acesso dos indivíduos a bens e serviços sociais coletivos e das soluções das carências da vida cotidiana. A construção da cidadania, como um processo, exige a melhoria da qualidade de vida, fator que por si só contribuirá para impulsionar a participação coletiva dos sujeitos sociais. Assim, por via das premissas apresentadas é possível declarar que a qualidade de vida está associada a construção da cidadania como um processo, então, sob tal perspectiva, apresentar-se-á o estudo de caso dos imigrantes haitianos em Manaus.

\section{Contextualização da Migração Haitiana}

O Haiti é um país das Grandes Antilhas, que ocupa o terço da ilha ocidental de Hispaniola². É limitado a norte pelo Oceano Atlântico, a leste pela República Dominicana, ao sul pelo mar do Caribe e a oeste pelo Canal de Ventilação, que separa a ilha de Cuba. O país estende-se por 27.750 km2. De acordo com as estimativas do Instituto Haitiano de Estatística e de Informática (IHSI, 2015), a população do país é estimada em 10.911.819 em 2015. Segundo o sociólogo haitiano, Laënnec Hurbon (1987), este país sempre foi abalado por situações de crises sócio-político-econômicas e ambientais que forçam grande parte da população a emigrar para buscar as oportunidades em terras estrangeiras.

Haiti, Cuba, Jamaica e Porto Rico são os quatro países do Caribe, formando as Grandes Antilhas. Nesta região, a dinâmica migratória (infra ou extra) do Caribe é muito avançada. Segundo O historiador haitiano Leslie François Manigat (2007), existem duas categorias de países do Caribe: de um lado, países com tradições migratórias, como Haiti, Jamaica, República Dominicana, Barbados, Suriname, Santa Lúcia, Porto Rico, Trinidad e Tobago; e, por outro lado, os países receptores de imigrantes que são as possessões francesas (Guadalupe, Guayana Francesa, Martinica), as Bahamas e as Ilhas Virgens Britânicas.

A dinâmica migratória (intra ou extra) do Caribe faz parte da história do Haiti. Os nativos que desapareceram no período genocida colonial espanhol (1494-1697), foram substituídos por homens e mulheres africanos, que são exportados por migração forçada para trabalhar nos campos

\footnotetext{
${ }^{2}$ Deve-se enfatizar que a ilha da Hispaniola ou (do Haiti) é dividida em duas republicas (pais): no leste, fica a República Dominicana e o Oeste, fica a República do Haiti. Deve-se notar que o nome foi dado pelos colonizadores espanhóis desde 1492.
} 
como escravos através pelo comércio triangular. Neste sentido, Audebert (2012) declarou que o Haiti nasceu de uma migração forçada.

Após a independência do país, em 1804, o fenômeno migratório continua existindo em outras formas e por outras causas. O Estado haitiano estabeleceu um sistema semifeudal, após o assassinato de Dessalines ${ }^{3}$ (1806), que exigia que os camponeses haitianos recém-libertos da escravidão continuassem trabalhando a terra em benefício das forças oligárquicas. Esses camponeses, para fugirem desse sistema, praticavam o marronage (migração forçada) (AUDEBERT, 2012). E, de acordo com o autor, esta primeira forma de migração, testemunhou o desejo dos haitianos em serem livres, pois os camponeses haitianos afirmam que continuam a trabalhar a terra para as oligarquias, ou seja, ainda estão na condição de um escravo. O povo haitiano desenvolveu a migração como forma de resistência contra a organização social, econômica e política estabelecida pelo Estado haitiano desde a independência de 1804. Eles estabeleceram o padrão de migração que, para Hurbon (1987), no imaginário haitiano, a mobilidade interna e externa tornou-se uma prática sociocultural.

Segundo Audebert (2012), Hurbon (1988) e Etienne (1997), no início do século XX, a migração externa do Haiti foi determinada por elementos econômicos, causada pela ocupação norte-americana, que fez surgir uma dupla perspectiva no país: pautada pelo contexto da evolução política e econômica do Haiti e pelo contexto da divisão internacional do trabalho criado pelos Norte-Americanos.

Segundo Castor (1988), a intenção dos EUA para controlar toda a América Latina e o Caribe, em harmonia com a Doutrina Monroe (1823), explicita-se na frase "América para os americanos". Assim, os Estados Unidos materializaram sua dominação por meio de uma política de expansão em todo o Caribe. Essa ocupação para estabelecer indústrias, causou a expropriação das terras dos camponeses, gerando uma grave degradação das condições de vida dos camponeses haitianos por terem sido desapropriados do único recurso que possuíam: seus territórios (HURBON, 1987). De fato, esse período foi marcado por um profundo agravamento da desigualdade social, e o sistema estabelecido falhou em atender as necessidades urgentes do povo no país. Consequentemente, o Estado haitiano, em conjunto com os imperialistas norte-americanos criaram planos e programas de migração oficiais para trabalhadores haitianos com apoio das autoridades de outros países do Caribe, particularmente Cuba e República Dominicana (DUBOUT, 1973: apud JEAN BAPTISTE, 2018).

Após a ocupação americana (1915-1934), o país experimentou uma severa ditadura militar com a dinastia de Duvalier (pai e filho), que durou quase 30 anos (1957 a 1986). Este regime estabeleceu no país um controle estrito sobre todas as estruturas do país. Os opositores políticos foram perseguidos, mortos, violados e exilados. Neste período, o Haiti experimentou uma nova onda de migração, mas, desta vez, esses migrantes seguiram em direção à América do Norte (Estados Unidos e Canadá) e para alguns países europeus, especialmente a França. Audebert (2011) indica que durante essa ditadura, 50.000 haitianos de todas as categorias sociais emigraram para os Estados Unidos da América e 3.600 para o Quebec.

Após a dinastia dos Duvalier, o país experimentou em sua história, novas ondas de migração. Além das causas tradicionais que explicam o deslocamento massivo de haitianos, esta

\footnotetext{
${ }^{3}$ Jean-Jacques Dessalines foi um dos principais líderes da Revolução Haitiana que proclamou a independência do país em 1 janeiro de 1804 e foi seu primeiro governante. Em 1805, seguindo os passos de Napoleão Bonaparte, proclamouse Imperador com o nome de Jacques I. Durante seu governo, tentou estabelecer um sistema inclusivo, favorável com a população de baixa renda. Foi traído e assassinado no dia de 17 de outubro de 1806 pelas forças oligárquicas do país (MANIGAT, 2007).
} 
última onda também foi impulsionada por atos da insegurança pública, ambiental e social no país (HURBON, 1987).

Os anos de 1990, simbolizaram, no plano político, o início da era democrática no Haiti. A população começou a experimentar a prática democrática com a organização das primeiras eleições democráticas, que elegeram Jean Bertrand Aristide à presidência do país. Todavia, um ano depois de assumir o cargo, ele foi derrubado do poder por um golpe militar. Os Estados Unidos se opuseram a esse Estado golpista e exigiram um retorno à ordem democrática e, como pressão eles impuseram ao país um embargo econômico de três anos. Assim, em 1994, por ordem dos Estados Unidos, o Presidente Aristide retornou ao país para completar seu mandato constitucional de cinco anos. Após seu retorno à chefia do país, Aristide procedeu à destruição do exército haitiano, para substituí-lo por uma força policial chamada Polícia Nacional do Haiti (PNH). No entanto, segundo Audebert (2012), o presidente Aristide instituiu grupos de bandidos armados no país, na forma de uma organização popular para defender seu poder. Isso criou um clima de terror no país, causando a emigração de muitos milhares de cidadãos haitianos.

Pelo fato do Haiti sempre estar posicionado como o país mais pobre das Américas, os cidadãos haitianos entendem que suas chances reais de ascensão social estão localizada fora do país (COTINGUIBA, 2013). Durante o período pós-ditatorial, um dos fatores que atuou no agravamento do empobrecimento do povo haitiano foram às condições ambientais, pois o Haiti experimentou uma série de desastres naturais (ciclones, furacões, terremotos entre outros). Isso torna a população muito mais vulnerável do que antes, e o Estado foi incapaz de responder efetivamente à sua intervenção. Por exemplo, dados do Banco Mundial (2016) indicam que o Haiti sofreu o maior número de desastres naturais em comparação com todos os outros países da região do Caribe. Assim, em 2008, as tempestades e os furacões destruíram 15\% do Produto Interno Bruto (PIB) do país, e o terremoto de 12/01/2010 causou uma perda de 120\% do PIB, e, de maneira geral, as categorias mais pobres do país (agricultores) são as mais afetadas (BANCO MUNDIAL, 2011). 0 pior impacto ocorreu no mesmo ano de 2010, com a pandemia de cólera que atingiu o país inteiro, matando quase 10 mil pessoas, infectando mais de 800 mil pessoas (HENDERSON, 2015). Mediante esse triste quadro, um grupo de países, particularmente, o Brasil, abriu suas portas para receber os migrantes haitianos sem grandes garantias, entregando apenas um visto humanitário.

Segundo os dados oficiais de 2010, estima-se que a diáspora haitiana atingiu um milhão de pessoas, incluindo 450 mil nos Estados Unidos, 280.000 na República Dominicana, 74.000 no Canadá e 42.000 na França (BANCO MUNDIAL, 2011). No entanto, entre 2010 e 2020, tornou-se difícil mensurar os números exatos de emigrantes haitianos, tendo em conta a situação irregular de saída deles. Entretanto, de acordo com uma estimativa feita, em 2017, por uma organização internacional chamada International Crisis Croup (2017), há 2,5 milhões de emigrantes haitianos e seus descendentes, cuja soma, eles avaliam em torno de 3,5 milhões.

No entanto, se os migrantes haitianos foram para os países ocidentais, especialmente USA, Canadá e França nos últimos séculos, no caso da América Latina, especialmente no Brasil, a presença dos imigrantes haitianos aconteceu em uma data bem recente. Entre 1940 e o ano 2000, o número de haitianos em todo o território brasileiro não ultrapassou a cifra de 200 (Quadro 01). (IBGE, 2000). 
Quadro 01: Dados estatísticos do número haitianos no Brasil entre 1940 e 2000

\begin{tabular}{|c|c|}
\hline ANOS DA CHEGADA & NÚMERO DOS IMIGRANTES \\
\hline 1940 & 16 \\
\hline 1950 & 21 \\
\hline 1960 & 150 \\
\hline 1970 & 90 \\
\hline 1980 & 127 \\
\hline 1991 & 140 \\
\hline 2000 & 15 \\
\hline
\end{tabular}

Fonte: (IBGE, 2000 apud Santo André, 2015)

Entretanto, de 2010 a 2014, ocorreu uma presença elevada de imigrantes haitianos no Brasil. Os dados do Grupo de Apoio a Refregados e Repatriados (GARR-Haiti, 2015 apud, JEAN BAPTISTE, 2018) informaram a existência de 70 mil imigrantes haitianos no território brasileiro. E, entre eles, quase 10 mil aportaram na região Norte do país, particularmente em Manaus (COSTA, 2016). Segundo Silva (2016), cerca de 2.000 decidiram ficar em Manaus em busca de oportunidades.

Contudo, foi no bojo da redemocratização do Brasil que importantes alterações foram incorporadas ao cenário de proteção e direitos sociais, alterações que trouxeram impactos para a vida dos imigrantes. A Constituição Federal Brasileira de 1988 consagrou alguns direitos para os imigrantes documentados que vivem no país à semelhança daqueles que possuem os cidadãos brasileiros, com a afirmação: “(...) todos são iguais perante a lei, sem distinção de qualquer natureza, garantindo-se aos brasileiros e aos estrangeiros residentes no País a inviolabilidade do direito à vida, à liberdade, à igualdade, à segurança e à propriedade (...)" (BRASIL, 1988, art.05).

A CFB, sob este arcabouço, orientou a criação de outras legislações e políticas públicas e sociais, dentre elas, destacam-se; a Lei nº 8.742/93 - Lei Orgânica da Assistência Social (LOAS); a Resolução nº 145/04, que trata da Política Nacional de Assistência Social (PNAS), prevê o ordenamento dos serviços em rede para, a Proteção Social Básica - PSB e a Proteção Social Especial (de média e alta complexidade) - PSE.; a Resolução nº 130/05, referente à Norma Operacional Básica (NOB/SUAS) e a Resolução nº 109/09, que trata da Tipificação Nacional de Serviços Socioassistenciais (Resolução 109 /CNAS) e que orienta o Serviço de Acolhimento Institucional, instituindo:

- Acolhimento provisório - estrutura para abrigar pessoas do mesmo sexo, ou grupo familiar; previsto para situações de rua, de desabrigo por abandono, migração e ausência de residência, além das pessoas em trânsito;

- Indivíduos sem condições de autossustento- são aqueles não possuem condições de autossustento, prevendo duas modalidades de atendimento em unidades institucionais;

- Residência para acolhimento emergencial, com serviço de profissionais preparados, em qualquer horário, durante a realização de diagnóstico de cada situação e os devidos encaminhamentos.

No Sistema Único de Assistência Social (SUAS), seus princípios, SUAS diretrizes e SUAS competências federativas devem ocorrer de acordo com as demandas apresentadas com garantia em todos os níveis de proteção, sem exceção nenhuma no atendimento aos migrantes (MINISTÉRIO DO DESENVOLVIMENTO SOCIAL E AGRÁRIO, 2016, p. 18-23), tendo em vista que o conjunto de serviços existentes são destinados ao combate da situação de vulnerabilidade social decorrente da pobreza, da falta de acesso a serviços públicos e aos direitos ou nas deficiências e 
fragilidades de convivência ou socialização. Igualmente, em nível estadual, outras leis, resoluções e portarias que dizem respeito à população migrante foram elaboradas e implementadas, seguindo esse ordenamento nos níveis estadual e municipal.

O Programa Saúde nas Escolas-PSE (Port. nº 001, de 10/12/2008), normatiza que os serviços Socioassistenciais ao migrante poderão ser executados pelo município, especificando que: Art. $4^{\circ}$ $\S 3^{\circ}$ - "devem favorecer a reinserção social e familiar ao migrante [...]"; Art. 5 - "o acolhimento, a concessão de passe nos transportes rodoviário e ferroviário, a oferta de albergues, alimentação, higienização e vestuário.

A Resolução da Secretaria de Estado do Desenvolvimento Social (SEDESE) no 16 de 04/03/2009 uniformiza os critérios de repasse dos recursos financeiros concedidos pelo Estado, destinados ao cofinanciamento das ações Socioassistenciais continuadas, em conformidade com os Planos Municipais aprovados pela Secretaria e Conselho Estadual de Assistência Social (CEAS).

Para o atendimento dos imigrantes no território brasileiro concorrem também: os serviços Socioassistenciais de Proteção Social Básica; os Benefícios Assistenciais; os Programas de Transferência de Renda, entre os quais o Programa Bolsa Família. O PBF prevê garantia de renda às famílias migrantes em condições de equiparação às nacionais. Para garantir a efetivação do programa para o público migrante, o MDS publicou um Ofício Circular, em conjunto com SENARC/ MDS e SNAS/MDS (11/2/ 2014), sobre o cadastramento de estrangeiros no Cadastro Único para Políticas Sociais e acesso ao Programa Bolsa Família.

O Relatório do MDSA (2016) ressalta que não existe óbice ao cadastramento e à concessão de benefícios para estrangeiros, que são públicos das políticas sociais da mesma forma que os nacionais, desde que atendidos os aspectos de vulnerabilidade social. Conforme os princípios do SUAS (MINISTÉRIO DO DESENVOLVIMENTO SOCIAL E AGRÁRIO, 2016, p. 18) de:

a) Universalidade: todos os migrantes têm direito à proteção socioassistencial prestada a quem dela necessitar, com respeito à dignidade e à autonomia, sem discriminação de qualquer espécie ou comprovação vexatória da sua condição;

b) gratuidade: a assistência social aos migrantes deve ser prestada sem exigência de contribuição ou contrapartida;

c) integralidade da proteção social: o migrante tem direito a oferta das provisões em sua completude, por meio de conjunto articulado de serviços, programas, projetos e benefícios socioassistenciais (com ressalvas para o Benefício de Prestação Continuada que é previsto apenas para brasileiros natos ou naturalizados, conforme estabelece o Decreto no 6.214/2007);

d) dintersetorialidade: a oferta de serviços socioassistenciais aos migrantes deve se pautar pela integração e articulação da rede socioassistencial com as demais políticas e órgãos setoriais.

No município de Manaus, a Secretaria Municipal de Saúde - SEMSA possui a responsabilidade de adotar todas as medidas cabíveis e necessárias para proteção da saúde da população em trânsito, minimizando os riscos decorrentes da situação de anormalidade. Então, as competências dos Entes Federativos do Brasil são definidas em termos de responsabilidades específicas para garantir que os direitos dos imigrantes sejam respeitados de acordo com os padrões estabelecidos pelas Nações Unidas desde 1948.

Para abordar a qualidade de vida dos imigrantes haitianos em Manaus, parte-se do reconhecimento de que estes sujeitos sociais vivenciam o conjunto de problemáticas vigentes no 
contexto urbano industrial como expressão da questão social. No entendimento destes agentes, a busca, via migração, para ter acesso aos bens e serviços sociais inerentes a condição de cidadania possibilitaria uma qualidade de vida digna.

\section{Qualidade de Vida dos Imigrantes Haitianos na Cidade de Manaus/AM}

Para analisar, sob uma perspectiva crítica, a qualidade de vida dos imigrantes haitianos na cidade de Manaus, capital do Estado do Amazonas, parte-se da consideração de quatro dimensões fundamentais: socioeconômico, psicológico, biométrico e geral ou holístico (PEREIRA, TEIXEIRA \& SANTOS, 2012). No contexto deste artigo, embora sejam consideradas as diferentes dimensões propostas, a abordagem analítica foi centrada no entendimento de que a concepção que norteia o termo qualidade de vida, em suas múltiplas dimensões, guarda complexa e dinâmica organização de seus elementos, pois a percepção individual resguarda singularidades, mesmo que os indivíduos partilhem vínculos socioculturais. Outrossim, serão consideradas também, sem muito aprofundamento, as características subjetivas como valores, interesses e as condições de salubridade. Ao buscar efetuar uma abordagem analítica abrangente da qualidade de vida, como forma de superar o reducionismo, que aborda esse conceito apenas sob a ótica da representação social pautada em parâmetros centrados na subjetividade dos indivíduos, como bem-estar e realização pessoal, considera-se igualmente os aspectos materiais (objetivos), que cinge também o atendimento às necessidades básicas e às impostas pela dinâmica consumista da sociedade contemporânea (PEREIRA, TEIXEIRA e SANTOS, 2012).

Como já foi relatado, a presença dos imigrantes haitianos na cidade de Manaus constitui-se um fenômeno novo na história da cidade. As primeiras levas de imigrantes haitianos ocorreram no início de 2010, após o terrível terremoto que devastou o Haiti, em 12/01/2010 12 DE JANEIRO DE 2020. Segundo Costa (2016), responsável da Pastoral dos Migrantes em Manaus, a chegada dos imigrantes foi uma surpresa para as autoridades públicas e religiosas da cidade e para a população manauara.

Além disso, no imaginário dos imigrantes e para os agentes sociais que os acolheram, Manaus seria uma rota de trânsito para as outras cidades do país e não destino como aconteceu. A esse respeito, Silva (2016, p. 183) declarou:

Em 2010, quando começaram a chegar os primeiros haitianos na cidade de Manaus, a ideia que parecia predominar naquele momento entre os agentes sociais que os acolhiam era a de que a cidade seria apenas um lugar de "passagem", já que para muitos deles o Brasil das "oportunidades" do qual eles tinham ouvido falar ficava mais a sudeste e sul, isto é, São Paulo, Rio de Janeiro, Curitiba. Florianópolis, entre outras. Manaus não parecia fazer parte do imaginário migratório que fora construído ainda no Haiti ou na República Dominicana, um dos principais locais de partida.

Como a presença da imigração foi uma surpresa para as autoridades da cidade, isso significa que não havia nenhum plano para acomodar os migrantes de maneira adequada. De acordo com Pe. Germino Costa (2016), as autoridades políticas da cidade foram quase totalmente ausentes em relação aos cuidados e aos processos a serem tomados. Portanto, nesse momento ocorreu um movimento conjunto de organizações religiosas, especialmente a Pastoral dos Migrantes e ONGs com ações para o acolhimento dessas pessoas. 
Os recém-chegados, em sua maioria jovens, de gênero (sexo) masculino, na faixa etária entre 18 e 45 anos, foram visivelmente identificados nos bairros populares da cidade de Manaus, tais como Chapada, São Geraldo, São Jorge, São Raimundo, Manoa, Zumbi, Mutirão, Cidade Nova. Sobre essa situação, Silva (2014) afirma que, em geral, os migrantes passaram a ocupar casas ou quartos alugados, pequenos e pouco arejados, onde várias pessoas ficavam agrupadas, pois esta tornou-se a alternativa para dividir os custos do aluguel. Ou seja, as condições sociais e sanitárias dos imigrantes na cidade formaram um espaço de vulnerabilidade, instabilidade e insegurança.

Em bairros da Zona Leste da cidade de Manaus foi constatado, durante a pesquisa, a existência de mais de uma quinzena de imigrantes acumulados em um quarto, assim como na área externa, em que mais de uma dúzia de pessoas chegaram a ocupar um espaço restrito. Igualmente, as condições sanitárias são extremamente precárias. Ao ser entrevistado, o Sujeito 4 expressou sua opinião sobre a situação enfrentada:

Para mim, os imigrantes haitianos são mais desprezados, humilhados em Manaus. Sob o pretexto de que os haitianos são corajosos e gostam de trabalhar, os chefes de empresas nos dão um tratamento desumano. (Sujeito 4).

A vida dos imigrantes é extremamente difícil na cidade pela dificuldade de obterem acesso efetivo aos serviços e bens sociais básicos nas áreas da saúde, transporte, educação, moradia, trabalho, lazer, entre outros. Para sobreviver, alguns deles se envolvem em atividades laborais informais. Assim, são visivelmente encontrados nas ruas manauaras vendendo água, picolés, bananas e outros gêneros.

A realização de observação participante em vários eventos junto aos imigrantes haitianos na cidade, bem como a análise dos relatos, permitiu sublinhar um conjunto de desafios enfrentados por esses imigrantes na cidade, tais como: a dificuldade para obter os documentos oficiais; a dificuldade de comunicação pela necessidade de utilizar a língua portuguesa; a necessidade de inserção no mercado de trabalho; as precárias, insalubres e de risco ambiental nas condições de moradia.

Vale ressaltar a existência de certos serviços sociais básicos na cidade para imigrantes, de acordo com os requisitos da constituição do país e certos acordos internacionais assinados pelas autoridades brasileiras. No entanto, o acesso a esses serviços nem sempre é fácil para os imigrantes haitianos que não dominam bem a língua portuguesa, e a grande burocracia que existe nas instituições brasileiras, o que claramente é relatado pelos Sujeitos 3 e 8:

Não recebi nenhum apoio do Estado brasileiro. Bem, talvez, esteja nos documentos, porque não paguei pelo CPF, nem pelos documentos da polícia federal. Mas havia muitas dificuldades para ter acesso com esses documentos, porque eu não falei a língua portuguesa, e nem eles não falam crioulo haitiano, nem francês (SUJEITO 3).

O Sujeito 3 informou que apesar de não receber apoio junto às instituições da cidade, o mesmo habita em um centro de acolhimento há mais de um ano sem arcar com nenhum custo. Posteriormente, o Sujeito 8 relata que está acostumado a frequentar os hospitais públicos da cidade. No entanto, o maior obstáculo encontrado é a incapacidade de estabelecer diálogos em português com os médicos.

A última vez que fui a um hospital aqui, foi muito difícil para o médico me atender, porque eu não falei português e ele também não sabia falar a minha 
língua. Foi graças a um amigo que estava aqui antes de mim, que consegui falar bem português, que voltou comigo cerca de uma semana para que eu pudesse conversar com o médico. Sim, os hospitais são gratuitos, mas os procedimentos são muito longos. Você deve marcar uma consulta, talvez não consiga encontrar as datas disponíveis e sofrerá muito. Às vezes, morremos antes que a data esteja disponível. Seria melhor ir a um hospital particular, mas não há dinheiro (SUJEITO 8).

Outro problema, destacou o Sujeito 8, é a existência de burocracia nas instituições brasileiras que, segundo ele, representa um dos principais obstáculos ao acesso aos serviços públicos na cidade de Manaus:

Qualquer coisa para encontrar aqui, tem que fazer muitas coisas antes de encontrá-lo. Tem que ter o CPF, RNM, carteira medical, carteira de trabalho etc. Bem, como eu, que não falo a língua dessas pessoas, poderei ter acesso com esses serviços? E não é fácil encontrar um haitiano disponível para ajudar a fazer todas essas coisas, porque todo mundo está fazendo suas próprias coisas. É por isso que eu fiquei ilegal desde mais de um ano aqui (SUJEITO 8).

Travassos e Castro (2008 apud EVLYN, LÍRIA, 2018, p. 137), indicam que existem obstáculos que podem impedir que os imigrantes acessem os serviços no território anfitrião, mesmo que tenham direito a esses serviços. Eles mencionaram os seguintes obstáculos:

(i) geográficos (relacionadas à disposição espacial dos serviços, sendo levado em consideração o quão próximo ou distante estão dos usuários, assim como o trajeto a ser percorrido);

(ii) financeiras (disponibilidade ou indisponibilidade de recursos financeiros necessários para acessar os serviços);

(iii) organizacionais (relativas à forma de oferta dos serviços e suas provisões, aos recursos humanos disponíveis para o atendimento, aos horários e estrutura física de atendimento);

(iv) informacionais (posse de informações acerca de direitos, existência de ofertas, formas de acesso);

(v) culturais (vinculadas à trajetória histórica dos usuários, às suas concepções, valores, experiências, subsidiadas pela construção social da qual fazem/fizeram parte).

No caso dos imigrantes haitianos na cidade de Manaus, é evidente que as dificuldades relacionadas ao domínio do português e a ausência de intérpretes nos locais de atendimento, adicionado ao aspecto burocrático das instituições públicas na cidade manauara, são as três maiores queixas em termos de dificuldades enfrentadas pelos imigrantes haitianos. Assim, deve-se atentar que, em termos de acesso aos serviços, ofertado para os imigrantes haitianos em Manaus, apresenta um problema de origem, uma vez que a dificuldade de comunicação compromete o processo como um todo, portanto essa realidade é a base de um conjunto de preconceitos vivenciados na cidade de Manaus e que afetam negativamente a qualidade de vida deles.

O preconceito, no sentido de Santos (2001, p.82), é "um modo de ver certas pessoas ou grupos raciais [...] de qualquer tipo. Ele é sempre uma atitude negativa em relação a alguém. [...] é uma atitude antecipada e desfavorável contra algo. Essa atitude pode ser tomada em relação a um indivíduo, a um grupo ou mesmo a uma ideia". Desse fato, os preconceitos constatados nos relatos dos sujeitos entrevistados se manifesteam sob a forma étnico-racial (haitiano/preto), do estatuto social (ser imigrante) e da sexualidade ou hipersexualização (haitianos/objeto sexual). No relato do Sujeito 5, ele afirma que: "Outra questão que existe no mercado de trabalho para 
os imigrantes haitianos em Manaus é que as empresas nos concebem como um povo desprovido de inteligência. As empresas não valorizam nossa potencialidade."

Um outro aspecto importante que chama a atenção sobre a situação de vida desses imigrantes na cidade, com traço de preconceito, é a questão da agressão sexual. Mais de 50\% dos interlocutores da pesquisa afirmaram já terem sido agredidos por homossexuais. Por exemplo, o Sujeito 2 afirma:

(...) eu já tenho sofrido preconceito. Os gays aqui não têm respeito com os haitianos. Alguns deles costuram de me agredir sexualmente, só porque sou negro. (...) um gay, entrou até no abrigo uma vez no meia noite para nos agredir. Demais, havia um brasileiro que me bateu muito perto da paróquia de São Gerado, sob o pretexto que eu não quis beijar ele (SUJEITO 7).

Entende-se que esses tipos de preconceito sobre essa categoria se manifestam da seguinte forma: como o resultado do contexto global da problemática racial no Brasil; do contexto pontual da migração haitiana pelo Brasil sobre resolução por razão humanitária (ver as resoluções normativas nº 92 de 12/01/2012 e nº 102/2013); e da construção estereotipada do ser haitiano como um individuo sem educação, associado como pertencente a uma população que vive na extrema pobreza no seu país. Essa última construção faz parte da tendência estereotipada veiculada pelas Organizações Internacionais e as ONGs para as campanhas de sensibilização internacional, com objetivo de justificar as intervenções sociais, militares, econômicas e políticas nesse país, ao longo da história.

Do Haiti ao Brasil (Manaus), os sonhos dos haitianos são transformados em simples ilusões. O quadro (Cf. Quadro 2) resume a qualidade de vida desses imigrantes do Haiti, passando pela tomada das decisões para emigrar até na permanência no território do Brasil (Manaus).

\section{Quadro 2: Do Haiti ao Brasil, os sonhos haitianos se transformam em uma utopia}

\begin{tabular}{|l|}
\hline Fatores expulsivos (Haiti) \\
\hline $\begin{array}{l}\text { Econômicos (empobrecimento, desemprego, exploração), políticos (perseguições, limites } \\
\text { `a participação), sociais (exclusão social, relações de subalternidade), ambientais (riscos e } \\
\text { vulnerabilidade aos desastres naturais) e culturais (desvalorização de seus saberes e práticas). }\end{array}$ \\
\hline Fatores Atrativos (deslocamento) \\
\hline $\begin{array}{l}\text { Econômicos (oportunidades de emprego, moradia), culturais (esperança, sonhos), políticos } \\
\text { (acessibilidade a bens e serviços sociais, democracia), sociais (dignidade, respeito) e } \\
\text { ambientais (salubridade, segurança alimentar). }\end{array}$ \\
\hline Permanência no Brasil (Manaus) \\
\hline $\begin{array}{l}\text { Econômicos (desemprego, condições precárias de vida, pobreza absoluta), políticos } \\
\text { (limitação à participação), sociais (discriminação), ambientais (alocação em áreas de risco e } \\
\text { vulnerabilidade, insalubridade) e culturais (desrespeito e desvalorização). }\end{array}$ \\
\hline
\end{tabular}

Fonte: Autor, 2020

No entanto, apesar das condições difíceis enfrentadas por esses imigrantes na cidade de Manaus, eles ainda mostram coragem e resiliência, denotando um profundo amor pelo país e pelo povo brasileiro. Na análise dos relatos do Sujeito 1, ex-professor de comunicação francesa no Haiti, teólogo por profissão, homem casado e pai de dois filhos, deixados no Haiti, e, atualmente, 
vendedor de picolés e água nas ruas manauaras, que manifestou o seu profundo amor pelo Brasil, apesar de não estar satisfeito com sua situação de vida.

Eu gosto do Brasil, porque o povo brasileiro é um povo muito hospitaleiro. Eles nos acolherem com alegria. Também, posso ir pelas ruas pedir trabalho, vender as coisas, banana, roupa. Eu vendo meu picolé e as pessoas já me conhecem, sempre compram de mim (SUJEITO 01).

Mas, em um segundo relato, o mesmo Sujeito 1 apresenta outro elemento que demonstra o contraste nas atividades dele: Eu passei de professor, pastor no Haiti a vendedor de picolé no Brasil (k). Coisas que eu nunca faria se estivesse no Haiti. Como o provérbio haitiano disse tão apropriadamente, trabalho é a liberdade. Então, eu fiz isso com alegria a fim de cuidar de minha família lá no Haiti (SUJEITO 01).

Dessa forma, percebe-se que não há acesso adequado às políticas de Assistência Social ao Migrante como definido na constituição do país. Diversos programas de inserção são falhos ou inexistentes, além da existência de barreira cultural e linguística que cerca o cotidiano dos imigrantes, que, agravando a condição de precarização e comprometendo a qualidade de vida destes indivíduos, que denota um distanciamento em relação ao que almejavam encontrar no Brasil, em alternativas ao país de origem. E ainda permanecem na cidade tendo a consciência que o panorama brasileiro, com todas as dificuldades existentes, é mais acolhedor e esperançoso que o haitiano, e, assim, continuam mantendo a esperança de que um dia a situação melhore.

Os resultados obtidos com o estudo revelaram que as condições de vida dos imigrantes haitianos na cidade de Manaus são extremamente difíceis pela falta de acesso efetivo aos bens e serviços sociais básicos de assistência social. Outrossim, identificou-se que a problemática que os imigrantes haitianos enfrentam decorrem principalmente das expressões da questão social inerente às contradições do sistema capitalista e da natureza restritiva, seletiva e precária da prestação de serviços das políticas públicas e afetam e comprometem sobremaneira à qualidade de vida.

A trajetória de vida dos haitianos sofre as inflexões, os fluxos e os refluxos, gerados pelo sistema de produção capitalista, em suas contradições, que instituem a questão social ao gerar o empobrecimento e a migração forçada destes sujeitos do Haiti para o Brasil. Assim, como no contexto local, os imigrantes sofrem um agravamento de suas necessidades humanas e sociais que incidem sobre a qualidade de vida, em razão da falta ou precariedade de atendimento às necessidades humanas fundamentais (alimentação, vestuário, habitação, lazer, bem estar e trabalho digno), pois vivenciam a exploração do trabalho (baixos salários, desrespeito aos direitos trabalhistas), o desemprego ou o emprego precário, além do desrespeito à sua identidade como ser haitiano (preconceito, discriminação).

\section{Considerações Finais}

Na contemporaneidade, o fenômeno da migração da pobreza associado às condições de acolhimento no âmbito das metrópoles é caracterizado pelo recrudescimento das contradições econômicas e político-sociais, sob a forma das problemáticas urbanas enfrentadas por diversos segmentos que se situam nas periferias das grandes cidades, que são relegados às áreas insalubres e vulneráveis que apresentam riscos sociais e ambientais. 
No caso dos imigrantes haitianos na cidade de Manaus, o enfrentamento de diversas dificuldades para acessar a cidadania em uma nova pátria, associa-se às lutas preexistentes no local de chegada, nos limites para conquista da cidade que são marcadas: pela exclusão social de vastos segmentos sociais (trabalhadores, sem teto, indígenas sem aldeia, migrantes entre outros); pela precariedade ou ausência de acesso aos bens e serviços sociais; e pela dificuldade de acesso às políticas públicas e sociais. Todavia, o processo de exclusão no contexto migratório ainda enfrenta um duplo processo de exclusão. 0 primeiro por estarem em um ambiente estranho ao de origem, e o segundo pela falta de políticas inclusivas e específicas para essa população. Ou seja, esse grupo além de enfrentar a barbárie de uma típica sociedade capitalista, vivencia a amplitude das expressões da questão social e os problemas estruturais da sociedade de chegada, e, assim, passam a entender que no contexto em que estão sendo inseridos a exclusão e as dificuldades de acesso tão cedo cessarão.

Porquanto, o poder público historicamente responde muito precariamente às demandas crescentes por serviços de consumo coletivo, levando ao crescimento acelerado e ao agravamento cada vez maior das carências das populações urbanas. Assim, mediante o exposto. defende-se que a qualidade de vida guarda uma complexa interdependência das condições: de acesso a bens e serviços de cidadania que abrange trabalho produtivo, educação, saúde e cultura; do ambiente de interação social dos indivíduos e/ou grupos e da participação cidadã; das relações interpessoais de convivência pela sociabilidade na vida cotidiana; da liberdade de expressão política; dos aspectos biopsicossociais associados aos valores e as necessidades humanas não-materiais (subjetivas). Obviamente, esse processo não é exclusivo da população migrante, pois uma expressiva parcela da sociedade local, no caso a manauara, também sofre anseios de busca pela qualidade de vida, que seja por pautada em condições sociais dignas. Todavia, a absoluta maioria dos imigrantes haitianos enfrenta profundas dificuldades em função de vivenciar exacerbadas condições de precariedade e de descaso.

Ao analisar as respostas dos sujeitos é perceptível que são pessoas ativas, que se posicionam de forma crítica pelo reconhecimento de serem protagonistas de sua história e com clareza sobre a condição a que estão submetidos, distinguindo as dificuldades econômicas e sociais, e percebem o óbvio, de que nem o mínimo é feito para garantir seus direitos humanos e sociais, pois o fluxo de serviços e o atendimento que deveriam existir ao chegarem na cidade inexiste, visto que a política é ineficaz e, portanto, lhes são tolhidos toda a condição de respeito e humanidade. Essa ausência é notada, ou seja, eles sabem o que lhes faltam, percebem e narram com nitidez as consequências desse processo cruel que vivenciam.

Por fim, embora haja um aparato jurídico-político legal que assegura a garantia de direitos (civis, sociais e políticos), que alicerça o conceito de cidadania e a vigência de acordos multilaterais entre países, sob a chancela de agências multilaterais para garantia de proteção social e direitos humanos, observa-se que a implementação da prática legal não é efetivada e os direitos não lhes são garantidos.

No estudo de caso efetuado não foi possível identificar quais as condições materiais concretas e subjetivas que estão disponíveis para serem usufruídas pelos imigrantes. Mas foi possível perceber que as contradições de classe, inerentes ao modo de produção vigente na sociedade, atinge de maneira inegável os imigrantes, gerando um rebatimento que afeta a qualidade de vida deste segmento social em seus diversos ângulos (socioeconômicas, psicológicas, biomédicas e holísticas). 


\section{Referências}

AUDEBERT, Cédric. La diaspora haïtienne: vers l'émergence d'un territoire de la dispersion? In: CELIUS, Carlo A. (Dir.). Le défi haïtien: économie, dynamique sociopolitique et migration, Paris: L'Harmattan, 2011, p. 193-212. Disponível em: <https://halshs.archives-ouvertes. fr/file/index/docid/817514/ filename/dispersion.pdf>.Acesso em: 10/12/ 2018.

BANQUE MONDIALE. Recueil de statistiques 2011 sur les migrations et les envois de fonds. 2011. Disponível em: <http://siteresources.worldbank.org/INTPROSPECTS/ Resources/334934-1110315015165/Factbook2011French.pdf>. Acesso em: 5 dez. 2019.

BARBOSA, Sônia Regina da Cal Seixas. Qualidade de Vida e ambiente: uma temática em construção. In: BARBOSA, Sônia Regina da Cal Seixas (org.). A temática ambiental e a pluralidade do Ciclo de Seminários do NEPAM. Campinas: UNICAMP, NEPAM, 1998, p. 401- 423.

BRASIL. Constituição da República Federativa do Brasil. Brasília: Senado Federal, 1988.

BRASIL. Resolução no 145/04 - Política Nacional de Assistência Social (PNAS).Disponível em: <http:// www.mds.gov.br/sobreoministerio/legislacao/assistenciasocial/resolucoes/2004/Resolucão CNA>. Acesso: 20 de fev. 2019.

BRASIL. Resolução no 109/09 - Tipificação Nacional de Serviços Sócio-assistenciais. Disponível em: <http://www.mds.gov.br/sobreoministerio/legislacao/assistenciasocial/resolucoes/2009/Resolucao CNA>. Acesso: 17 de fev. 2019.

COELHO, Lígia Martha C. Sobre o Conceito de Cidadania: uma crítica a Marshall, uma atitude antropofágica. In: Coelho, Lígia Martha C. et al. Cidadania/Emancipação. Rio de Janeiro. Tempo Brasileiro. 1990.

CASTEL, Robert. As Metamorfoses da Questão Social: uma crônica do salário. Rio de Janeiro, Vozes, 1998.

CASTOR, Suzy. L'occupation américaine d'Haiti. Imprimerie Henry Deschamps, Portau-Prince, 1988.

CERQUEIRA FILHO, Gisálio. A Questão Social no Brasil - Crítica do Discurso Político. 1982.

COSTA, Pe. Gelmino. Cadernos de migração: memória da chegada de imigrantes haitianos a Manaus, 2010-2014: Presença da Pastoral do Migrante. Centro de Estudo de Migratórias. São Paulo, 2016.

DAY, H. ; JANKEY, S.G. Lições da literatura: em direção a um modelo holístico de qualidade de vida. In: RENWICK, R.; BROWN, I.; NAGLER, M. (Eds.). Qualidade de vida na promoção e reabilitação da saúde: abordagens conceituais, questões e aplicações. Mil Oaks: Sage, 1996.

ETIENNE, Sauveur Pierre. Haïti, l'invasion des ONG. Editions du CIDlHCA, Quebec, 1997.

HANDERSON, Joseph. Diáspora: as dinâmicas de mobilidade haitiana no Brasil, no Suriname no Guiana francesa. Tese (Doutorado)- Programa de Pós-Graduação em Antropologia Social do Museu Nacional, UFRJ, 2015.

HURBON, Laënnec. Comprendre Haïti. Essai sur l'Etat, la nation, la culture. Karthala, Paris, 1987.

IAMAMOTO, Marilda V. O Serviço Social na Contemporaneidade: trabalho e formação profissional. $5^{a}$ ed. São Paulo: Cortez, 1999.

IANNI, Octavio. A Questão Social. Revista USP, (3), 145-154. 
INSTITUTO BRASILEIRO DE GEOGRAFIA E ESTATÍSTICA-IBGE. Censo Demográfico 2010. Disponível em: http://www.ibge-.gov.br/home/estatistica/populacao/censo2010/resultados \gerais $\backslash$ amostra-/ resultados \gerais \amostra \tab\uf $\backslash$ microdados. shtm. Acesso em 5 fev. 2019.

INSTITUTO BRASILEIRO DE GEOGRAFIA E ESTATÍSTICA - IBGE,1940; 1950; 1960; 1970; 1980; 1991; 2000; 2010 apud ARAÚJO, A. A. A. Reve de Brezil: A inserção de um grupo de imigrantes haitianos em Santo André- SP - Brasil.

INSTITUT HAÏTIEN DE STATISTIQUES E D'INFORMATIONS - IHSI. Population totale, population de 18 ans et plus ménages et densités estimés en 2015. Porto- Príncipe, 2015. Disponível em: < http://www. ihsi.ht/pdf/projection/Estimat PopTotal_18ans_Menag2015.pdf>. Acesso em: 03 fev. 2020.

INTERNATIONAL CRISIS GROUP. Global Overview. Disponivel em: https://www.crisisgroup.org/ crisiswatch/august-2017. Acesso em: 10 dec.2019.

JEAN BAPTISTE, Marc Donald. O Haiti está aqui: uma análise da compreensão dos Imigrantes Haitianos sobre a Política Social no Brasil. Dissertação (Mestrado em Serviço Social), UEL. 2018.

MANIGAT Lesly. F. Eventail d'Histoire Vivante d'Haiti: Des Preludes a la Revolution de Saint Domingue Jusqu'á nos Jours (1789-2007), tome 4. Media-Texte. 2007.

MARSHALL, Tomas Hamprey A. A cidadania, Classe Social e Status. Trad.: Merton Porto Gadelha. Rio de Janeiro: Zahar, 1997.

MINISTÉRIO DO DESENVOLVIMENTO SOCIAL E AGRÁRIO. Sistematização do debate sobre o papel da assistência social no atendimento aos migrantes. Brasília, maio de 2016.

NETTO, José P. Introdução ao método da teoria social. In:Serviço Social: direitos sociais e competências profissionais. Brasília: CFESS/Abepss, 2009.

NETTO, José Paulo. Sobre a Questão Judaica. Tradução Rubens Enderle e Leonardo de Deus, 1ำ ed. São Paulo: Editora Boitempo, 2005.

PEREIRA, Érico Felden; TEIXEIRA, Clarissa Stefani, SANTOS, Anderlei dos. Qualidade de vida:

abordagens conceitos e avaliação. Rev. bras. Educ. Fís. Esporte, São Paulo, v.26, n.2, p.241-50, abr./ jun. 2012.

RICO, Elizabeth de Melo. 0 empresariado, a filantropia e a questão social. Revista de serviço Social e Sociedade, № 58 ano XIX. São Paulo: Cortez, 1998. p. 37-38.

SARTRE, Jean Paul. Questions de Méthode: marxime et existealisme. Critique a la raison dialethique. Paris: Gallirmard, 1972.

SANTIN, Silvino. Cultura Corporal e Qualidade de Vida. Revista Kinesis, Sta. Maria/RS, Nov/2002, p. 116-186.

SILVA, Sidney A. Haitianos em Manaus, Mercado de trabalho e exercício da cidadania, 2014. In: SILVAL Sidney Antônio, ASSIS O. Glaucia. Em busca do Eldorado: o Brasil no contexto das migrações nacionais e internacionais. Editorial da Universidade Federal do Amazonas. 2016.

SPINK, Mary Jane Paris (org.). A Cidadania em Construção: uma reflexão transdisciplinar. São Paulo: Cortez, 1994.

WHOQOL, Qualidade de Vida na Organização Mundial da Saúde. Protocolo de estudo para o projeto da organização word 1 hrath para desenvolver um instrumento de avaliação da qualidade de vida. Res. Qualidade de vida., V.2, n.2, pág. 153, 1993. 